\title{
脳血管内治療と感染症
}

\author{
石原秀章 ${ }^{1)}$ 石原正一郎 1) 根木宏明 1) 大川原舞 ${ }^{11} \quad$ 金澤隆三郎 1) 神山信也 ${ }^{1)}$ 山根文孝 1) \\ 柴崎智美 ${ }^{2)}$ 前崎繁文 ${ }^{3)}$ 橋北義一 ${ }^{4)}$
}

\section{Infectious complications in neuroendovascular treatment}

\author{
Hideaki ISHIHARA $^{1)}$ Shoichiro ISHIHARA ${ }^{1)}$ Hiroaki NEKI ${ }^{1)}$ Mai OKAWARA ${ }^{1)}$ Ryuzaburo KANAZAWA ${ }^{1)}$ \\ Shinya KOHYAMA ${ }^{1)}$ Fumitaka YAMANE ${ }^{1)}$ Satomi SHIBAZAKI ${ }^{2)}$ Sigefumi MAESAKI ${ }^{3)}$ Giichi HASHIKITA ${ }^{4)}$ \\ 1) Division of Endovascular Neurosurgery, Stroke Center, International Medical Center,Saitama Medical University \\ 2) Community Health Science Center \\ 3) Department of Infection Disease and Infection Control \\ 4) Clinical Laboratory, Saitama Medicine School Hospital
}

\begin{abstract}
Objective: Endovascular treatment is thought to be minimally invasive and result in few infectious complications. However, in some cases, infectious complications occur due to the presence of intravascular foreign bodies. Previous studies have not provided sufficient data in this regard. Specifically, no studies on the frequency of sepsis following neuroendovascular surgery have been reported. Therefore, frequency of sepsis and associated risk factors were investigated in this study.

Methods: Serum samples and various cultures obtained after neuroendovascular surgical procedures ( $\mathrm{n}=153$ ) performed at our facility from September 2006 to September 2007 were examined. Frequency of bacteremia, sterility of the operating field, and associated risk factors were assessed.

Results: Twelve cases (7.8\%) had complicated bacteremia and were successfully treated with antibiotics. However, two cases developed MRSA infection, that proved to be intractable. Organisms were isolated from more than half of the operating field. Risk factors for bacteremia were surgical procedures involving tumor embolization (odds ratio $[\mathrm{OR}]$ 7.6, $\mathrm{P}=0.034$ ) and large sheath size (OR 3.9, $\mathrm{P}=0.047$ ). Risk factors for a contaminated operating field were the operating surgeon, surgical procedure, large sheath size and use of a hemostatic device, of which the surgeon was a significant risk factor (OR 0.5, $\mathrm{P}=0.049)$. The organisms responsible for bacteremia varid from normal bacterial flora to gram-negative rods and MRSA. As antibiotic prophylaxis was not found to be effective in these cases (OR 4.7, $\mathrm{P}=0.035)$, the appropriate type and course of antibiotics had to be selected to prevent such complications.

Conclusion: Bacteremia occurring following neuroendovascular treatment can develop in an uncontrollable manner. Thus, surgical procedures must be performed in a sterile environment, especially complicated procedures involving large sheaths.
\end{abstract}

OKey Words

bacteremia, endovascular treatment, infection, sepsis

1）埼玉医科大学 日高国際医療センター 脳卒中センター 脳血管内治療科

(Recieved March 3, 2008 : Accepted June 26, 2008)

2) 埼玉医科大学 地域医学医療センター

3）埼玉医科大学付属病院 感染症科・感染制御科

4) 埼玉医科大学付属病院 中央検査部

＜連絡先：石原秀章％350-1298 埼玉県日高市山根1397-1Ｅ-mail：hideaki@saitama-med.ac.jp＞

\section{はじめに}

近年脳血管内治療は，その低侵襲性と器材や手技の著 しい進歩により社会の注目を集めている，開頭手術と異 なり感染の危険性が少ないことも利点ではあるが，その 実態については不明であり，心臓や末梢の血管内治療で は異物感染による予後不良例も報告されている，脳血管
内治療は時に手技が繁雑で長時間に及ぶ場合もあり，血 管内に異物を挿入，留置する以上，血液感染については 特に注意を払うべきと考える。しかしながら，開頭手術 と比較すると血管内治療現場に打ける清潔操作は不十分 である懸念が残っている，今回，我々は，脳血管内治療 に打ける菌血症の発生率，術野の清潔度，その危険因子 を明らかにすることを目的とし検討したので報告する. 
Table 1 Cases with bacteremia

\begin{tabular}{|c|c|c|c|c|c|c|}
\hline case & age,sex & operation & $\begin{array}{c}\text { sheath size/ } \\
\text { duration (hours) }\end{array}$ & complication & risk factor & organisms \\
\hline 1 & $64 \mathrm{~F}$ & CAS & $8 \mathrm{~F} / 24$ & $\mathrm{AMI}+\mathrm{PCI}, \mathrm{CABG}$ & hemodialysis & MRSA \\
\hline 2 & $65 \mathrm{~F}$ & CAS & $8 \mathrm{~F} / 24$ & - & - & CNS \\
\hline 3 & $74 \mathrm{M}$ & CAS & $8 \mathrm{~F} / 24$ & cerebral embolism & - & - \\
\hline 4 & $72 \mathrm{~F}$ & $\mathrm{CAS}$ & $8 \mathrm{~F} / 24$ & - & - & MSSA, Enterococcus \\
\hline 5 & $57 \mathrm{M}$ & meningioma, embolization & $5.2 \mathrm{~F} / 3$ & - & steroid & corynebacterium \\
\hline 6 & $47 \mathrm{M}$ & meningioma, embolization & $5.2 \mathrm{~F} / 3$ & - & steroid & - \\
\hline 7 & $69 \mathrm{M}$ & $\begin{array}{c}\text { unruptured cerebral aneurysm, } \\
\text { coil embolization }\end{array}$ & $6.2 \mathrm{~F} / 3$ & - & - & - \\
\hline 8 & $63 \mathrm{M}$ & $\begin{array}{l}\text { ruptured cerebral aneurysm, } \\
\text { coil embolization }\end{array}$ & $5.2 \mathrm{~F} / 20$ & & $\mathrm{CV}$ & $\operatorname{gram}(+)$ bacilli \\
\hline 9 & $54 \mathrm{M}$ & $\begin{array}{c}\text { ruptured cerebral aneurysm, } \\
\text { coil embolization }\end{array}$ & $5.2 \mathrm{~F} / 24$ & - & $\mathrm{CV}$ & CNS \\
\hline 10 & $51 \mathrm{~F}$ & spasm, PTA & $6 \mathrm{~F} / 24$ & - & $\mathrm{CV}$ & - \\
\hline 11 & $54 \mathrm{M}$ & spasm, transarterial infusion & $5.2 \mathrm{~F} / 24$ & - & $\mathrm{CV}$ & MRSA \\
\hline 12 & $57 \mathrm{~F}$ & AVM, NBCA embolization & $7.2 \mathrm{~F} / 24$ & hemorrhage & $\mathrm{CV}$ & fungus \\
\hline
\end{tabular}

AMI: acute myocardial infarction, AVM: arteriovenous malformation, CABG: coronary artery bypass graft, CAS: carotid artery stenting, CNS: coagulase negative staphylococcus, CV: central venous catheter, MRSA: Methicillin resistant staphylococcus aureus, MSSA: Methicillin sensitive staphylococcus aureus, NBCA: N-butyl cyanoacrylate, PTA: percutaneous tlansluminal angioplasty, PTCA: percutaneous transluminal coronary angioplasty,

\section{方 法}

対象は当施設における2006年 9 月から2007年 9 月まで のすべての血管内治療133症例（男63例，女70例)，平均 年齢61歳 (23歳〜93歳), 153 手技である [脳動脈瘤塞栓 術62手技，内頸動脈ステント留置術 (carotid artery stenting：CAS）29手技，脳動静脈奇形（arteriovenous malformation：AVM）塞栓術20手技，薬物動注19手技， 経皮的血管拡張術 (percutaneous transluminal angioplasty：PTA） 9 手技，腫瘍塞栓術 9 手技，硬膜 下血腫塞栓術 5 手技]. 菌血症の指標として, これらに 対して脳血管内治療終了後, 動脈血培養（シースから採 取), カテーテル先端培養, パームチェック培養 (手形 の培地に術後手袋を押し付けて培養), 血清学的検查 (工 ンドトキシン， $\beta$-Dグルカン）を施行した。同じ術野 で作業をした術者，助手の清潔度には大差はないと判断 し, パームチェックは術者のみを対象とした. 菌血症は, 他に原因がなく著明な炎症反応 $\left(38^{\circ} \mathrm{C}\right.$ 以上の発熱かつ CRPの上昇）を認めたものとし，培養検査は偽陰性も 多いことから必ずしも陽性でないものも含めた。抗生剤 の予防投与は原則行わない方針としたが，ステロイド投 与例, 血液透析患者などの易感染性の 2 例, 開頭術後, 脳室脊髄ドレナージチューブ留置例，肺炎合併例など他 の要因を要する25例には血管内治療時に抗生剂を投与し た。
危険因子として, 患者の既往（糖尿病，ステロイド投 与), 手術手技（緊急度，術式，手技時間，シースサイ ズと留置時間，長いガイドワイヤーや止血器具などの使 用，不潔操作，血栓出血合併症などの有無), 術場, 術 者（当施設に打ける年齢順，経験豊富なものから $\mathrm{AB}$ ・ とした), 中心静脈ルートや持続血液透析など他の感染 源の有無, 術野清潔度（パームチェック培養）などを検 討した。菌血症の有無と危険因子, 術野清潔度と危険因 子との関連についてロジスティック回帰分析を用いてオ ッズ比を算出した. 統計はSASのLOGISTIC PROCEDUREを用いた。

\section{結 果}

菌血症は12例（7.8\%）に認められた（CAS 4 例，破 裂脳動脈瘤 4 例，髄膜腫塞栓術 2 例，未破裂脳動脈瘤 塞栓術 1 例，脳動静脈奇形塞栓術 1 例)。髄膜腫の 2 例 はステロイドを服用しており，また破裂脳動脈瘤と脳動 静脈奇形の 5 例は長期臥床で中心静脈ルートを留置して いた（Table 1)。全例抗生剤投与により軽快し，異物感 染徵候はなく，その後の合併症も認めなかった。MRSA 感染の 2 例は難治性であり抗生剂投与を 1 力月以上要し た.

\section{1. 菌血症の有無と危険因子の検討}

単変量解析にて術式ではCAS と腫瘍塞栓術が，個々 の手技では大きなシースサイズの関連が有意であった。 
Table 2 Risk factors for bacteremia

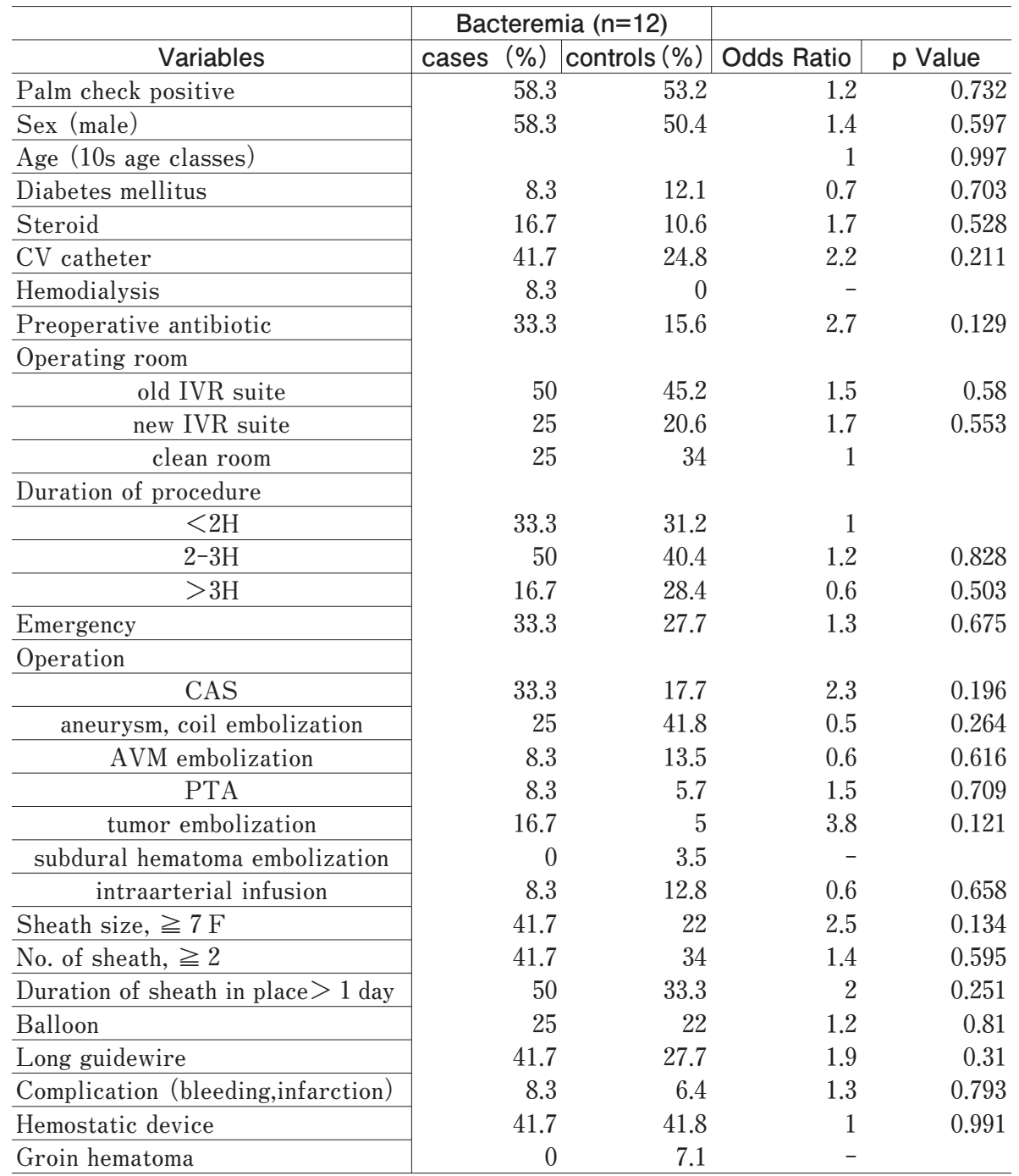

中心静脈ルートも感染率を上げる傾向にあったが，統計 上有意差を認めなかった (Table 2). 多変量解析を行う と，抗生剤投与 (odds ratio [OR] 4.7; $\mathrm{P}=0.035$ )，大き なシースサイズ ( $\mathrm{OR} 3.9 ; \mathrm{P}=0.047)$ ，腫瘍塞栓術（OR 7.6; $\mathrm{P}=0.034 ）$ の関連が有意であった（Table 3).

\section{2. 術野清潔度と危険因子の検討}

単変量解析では，特定の術者（経験豊富で潔癖なC) (OR 0.4; $\mathrm{P}=0.013$ ), 術式（薬物動注OR 0.4; $\mathrm{P}=0.046$ ), 大きなシースサイズ ( $\mathrm{OR} 2.3 ; \mathrm{P}=0.032)$, 止血器具 $(\mathrm{OR}$ 2.6; $\mathrm{P}=0.005)$ の関連が有意であった (Table 4). 多変 量解析では特定の術者 (助手) (OR 0.5; $\mathrm{P}=0.049)$ のみ の関連が有意でありオッズ比 0.5 倍と不潔になりにくい 傾向にあった（Table 5).

\section{3. 起因菌について}

菌血症症例ではCNS (coagulase negative staphylococcus）以外に，MRSA，グラム陰性桿菌など多種の存 在が確認された。パームチェックでは86例（54.8\%）に 皮膚常在菌，落下細菌が認められ術野の清潔度に問題が あることが確認された（Table 6)。

\section{考察}

脳血管内治療の血液感染性合併症についてロジスティ ック回帰分析を用いて検討したところ，菌血症の危険因 子として抗生剂投与，大きなシースサイズ，ステロイド 使用例での腫瘍塞栓術の関連が有意であり，術野清潔度 の危険因子としては特定の術者 (助手) の関連が有意で あった，血管内治療はその低侵襲性から，開頭手術とは 
Table 3 Multivariate logistic regression for bacteremia

\begin{tabular}{l|c|c|c}
\hline Risk Factors & OR & $95 \% \mathrm{Cl}$ & $\mathrm{p}$ value \\
\hline Preoperative antibiotic & 4.7 & $1.1-20.0$ & 0.035 \\
\cline { 1 - 1 } Sheath size, $\geqq 7 \mathrm{~F}$ & 3.9 & $1.0-15.0$ & 0.047 \\
\cline { 1 - 1 } Tumor embolization & 7.6 & $1.2-50.3$ & 0.034 \\
\hline
\end{tabular}

$\mathrm{Cl}$ : confidence interval, OR: odds ratio

Table 4 Risk factors for unclean operating field

\begin{tabular}{|c|c|c|c|c|c|}
\hline \multirow[b]{2}{*}{ Variables } & \multicolumn{3}{|c|}{ Palm check positive $(n=86)$} & \multirow[b]{2}{*}{ Odds Ratio } & \multirow[b]{2}{*}{ p Value } \\
\hline & cases & $(\%)$ & controls (\%) & & \\
\hline Sex (male) & \multirow{2}{*}{\multicolumn{2}{|c|}{52.4}} & \multirow[t]{2}{*}{49.3} & 1.1 & \multirow{2}{*}{$\begin{array}{l}0.698 \\
0.444\end{array}$} \\
\hline Age (10s age classes) & & & & 1 & \\
\hline Diabetes mellitus & \multicolumn{2}{|r|}{13.4} & 9.9 & 1.4 & 0.498 \\
\hline Steroid & \multirow{2}{*}{\multicolumn{2}{|c|}{$\begin{array}{r}9.8 \\
23.2\end{array}$}} & 12.7 & 0.7 & 0.568 \\
\hline $\mathrm{CV}$ catheter & & & & 0.7 & \multirow[t]{2}{*}{0.369} \\
\hline Hemodialysis & \multicolumn{2}{|r|}{$\begin{array}{r}1.2 \\
146\end{array}$} & 0 & - & \\
\hline Preoperative antibiotic & \multirow{2}{*}{\multicolumn{2}{|c|}{14.6}} & \multirow[t]{2}{*}{19.7} & \multirow[t]{2}{*}{0.7} & \multirow[t]{2}{*}{0.405} \\
\hline Operating room & & & & & \\
\hline old IVR suite & \multirow{4}{*}{\multicolumn{2}{|c|}{$\begin{array}{l}34.1 \\
25.6 \\
40.2\end{array}$}} & \multirow{3}{*}{$\begin{array}{l}59.2 \\
15.5 \\
25.4\end{array}$} & 0.4 & 0.008 \\
\hline new IVR suite & & & & 1 & 0.932 \\
\hline clean room & & & & 1 & \\
\hline Duration of procedure & & & & & \\
\hline$<2 \mathrm{H}$ & & 32.9 & 29.6 & 1 & \\
\hline $2-3 \mathrm{H}$ & & 37.8 & 45.1 & 0.8 & 0.462 \\
\hline$>3 \mathrm{H}$ & & 29.3 & 25.4 & 1 & 0.932 \\
\hline Emergency & & 28 & 28.2 & 1 & 0.987 \\
\hline Operation & & & & & \\
\hline CAS & & 23.2 & 14.1 & 1.84 & 0.156 \\
\hline aneurysm,coil embolization & & 37.8 & 43.7 & 0.784 & 0.462 \\
\hline AVM embolization & & 13.4 & 12.7 & 1.067 & 0.893 \\
\hline PTA & & 9.8 & 1.4 & 7.568 & 0.594 \\
\hline tumor embolization & & 6.1 & 5.6 & 1.087 & 0.904 \\
\hline subdural hematoma embolization & & 1.2 & 5.6 & 0.207 & 0.163 \\
\hline intraarterial infusion & & 7.3 & 18.3 & 0.352 & 0.046 \\
\hline Sheath size, $\geqq 7 \mathrm{~F}$ & & 30.5 & 15.5 & 2.392 & 0.032 \\
\hline No. of sheath, $\geqq 2$ & & 39 & 29.6 & 1.524 & 0.222 \\
\hline Duration of sheath in place $>1$ day & & 37.8 & 31 & 1.354 & 0.377 \\
\hline Balloon & & 24.4 & 19.7 & 1.313 & 0.489 \\
\hline Long guidewire & & 30.5 & 26.8 & 1.2 & 0.612 \\
\hline Complication (bleeding, infarction) & & 6.1 & 7 & 0.857 & 0.813 \\
\hline Hemostatic device & & 52.4 & 29.6 & 2.625 & 0.005 \\
\hline Groin hematoma & & 7.3 & 5.6 & 1.322 & 0.675 \\
\hline Operator $\quad \mathrm{A}$ & & & & 1.776 & 0.099 \\
\hline $\mathrm{B}$ & & & & 1.373 & 0.332 \\
\hline $\mathrm{C}$ & & & & 0.435 & 0.013 \\
\hline $\mathrm{D}$ & & & & 1.097 & 0.776 \\
\hline $\mathrm{E}$ & & & & 0.805 & 0.505 \\
\hline $\mathrm{F}$ & & & & 1.936 & 0.076 \\
\hline
\end{tabular}

異なり感染性合併症は軽視される傾向にあるが，近年そ の報告が散見されるようになった4)。エアフィルターの ない一般の血管造影室で手洗いなしで行われることが多 く，穿刺部位は污染されやすい鼠径部が主に使用され， 異物を直接血管内に出し入れする操作を伴うため感染し
やすい条件は揃っている，ステント留置に関しては，冠 動脈で約 $1 \%$ ，四肢末梢の分野で $0.04 \sim 6 \%$ の異物感染が 報告されており，元の際の心筋梗塞合併や四肢切断率は 10～60\%とされ，外科的治療を行っても死亡率10～50\% と予後不良である2)，脳血管内治療の分野では，脳動脈 
Table 5 Multivariate logistic regression for unclean operating field

\begin{tabular}{l|c|c|c}
\hline Risk Factors & OR & $95 \% \mathrm{Cl}$ & $\mathrm{p}$ value \\
\cline { 1 - 1 } Sheath size, $\geqq 7 \mathrm{~F}$ & 1.5 & $0.6-3.9$ & 0.383 \\
\cline { 1 - 1 } Hemostatic device & 1.9 & $0.9-4.2$ & 0.107 \\
\cline { 1 - 1 } Operator C & 0.5 & $0.3-1.0$ & 0.049 \\
\hline
\end{tabular}

Table 6 Organisms

\begin{tabular}{l|c|c}
\hline & bacteremia & palm check \\
\hline & $(\mathrm{n}=12)$ & $(\mathrm{n}=86)$ \\
\hline CNS & 6 & 60 \\
\cline { 1 - 1 } micrococcus & 4 & 31 \\
\cline { 1 - 1 } corynebacterium & 3 & 7 \\
\cline { 1 - 1 } Bacillus & 2 & 22 \\
\cline { 1 - 1 } candida albicans & 2 & 1 \\
\cline { 1 - 1 } MRSA & 2 & - \\
\cline { 1 - 1 } gram negative rods & 1 & 5 \\
\cline { 1 - 1 } Enterococcus faecalis & 1 & - \\
\cline { 1 - 1 } MSSA & 1 & - \\
\cline { 1 - 1 } Neisseria species & - & 1 \\
\hline
\end{tabular}

CNS: coagulase negative staphylococcus

MRSA: Methicillin registant staphylococcus aureus

MSSA: Methicillin sensitive staphylococcus aureus

瘤コイル塞栓術後の脳膿瘍 5 例の報告3) や，ステント感 染の報告1)もあるが，脳血管内治療全体での実態は明ら かではない，菌血症については血管造影検查で $4 \%$ ，治 療で32\%との報告もあるが，脳血管内治療においてはこ れまでに報告を見ない5,7)。冠動脈，四肢血管の分野で は感染の危険因子として, 手術時間, シースの長期留置, 頻回の穿刺, 長いガイドワイヤー, 複数のステント留置, 再ステント留置，局所の出血や止血デバイスの使用等が 挙げられている6).

今回の研究で，菌血症が良性腫瘍の塞栓術に多い傾向 にあったが，ステロイドの関連は有意でないうえに症例 も少なくその原因を説明するには至らなかった。 大きな シースサイズの関連が有意である理由としては，術式，

手技の繁雑性，止血器具の使用，留置時間などの個々の 因子も関与するものと思われたが多変量解析では有意差 を認めず，腫瘍塞栓術とともにもっと症例を集めた検討 が必要であると思われた。 ハイリスク例（中心静脈ルー 卜，ステロイド投与，血液透析等）では抗生剤を投与し ても易感染傾向にあり，起因箘も皮膚常在菌のみならず MRSAやグラム陰性桿菌など多種にわたることから，予 防抗生剂投与は種類，投与期間が重要であると考えられ た.
術野の清潔度については術者および助手の関連が有意 であり，手技に対する清潔観念が重要であると考えられ た。一般的に起因菌としては，急性期感染でStaphylococcus aureus，遅発性感染でCNSが多くを占める.今 回我々の研究に打いても菌血症, 術野の約半数から CNSが検出され, 術野での清潔操作が重要であること が示唆された。

今回，菌血症の合併が一定の確率で認められたものの 全例軽快しえたのは，皮膚常在菌が多い上に早期発見に よる抗生剤投与が有効であったためと考察された。 クモ 膜下出血急性期例やステロイド使用中の脳腫痬例など免 疫能低下を伴う症例では血管内治療により発生した菌血 症から重篤になりうる危険性を無視できず，より厳重な 清潔操作が必要である。治療に関わるスタッフは日常手 技に潜むこれらの危険性に関して再認識するとともに， 各施設に打ける現場での対策が必要であると考えられ た.

\section{参考文献}

1) Deiparine MK, Ballard JL, Taylor FC, et al: Endovascular stent infection. J Vasc Surg 23:529-533, 1996.

2 ) Ducasse E, Calisti A, Speziale F, et al: Aortoiliac stent graft infection: current problems and management. Ann Vasc Surg 18:521-526, 2004.

3 ) Jenkinson MD, Javadpour M, Nixon T, et al: Intracerebral abcess formation following embolisation of an internal carotid artery aneurysm using Guglielmi detachable coils. Acta Neurochir (Wien) 145:703-06, 2003.

4) Kaviani A, Ouriel K, Kashyap VS, et al: Infected carotid pseudoaneurysm and carotid-cutaneous fistula as a late complication of carotid artery stenting. J Vasc Surg 43:379-381, 2006.

5 ) Meyer P, Reizine D, Aymard A, et al: Septic complications in international angiography: evaluation of risk and preventive measures: preliminary studies. J Intervent Radiol 3:73-75 1988.

6) Ryan JM, Ryan BM, Smith TP: Antibiotic prophylaxis in interventional radiology. J Vasc Interv Radiol 15:547-556, 2004.

7 ) Samore MH, Wessolossky MA, Lewis SM, et al: Frequency, risk factors, and outcome for bacteremia after percutaneous transluminal coronary angioplasty. Am J Cardiol 79:873-877, 1997. 


\section{要 旨}

JNET 2:107-112, 2008

【目的】血管内治療は一般的に低侵襲で感染合併症が少ないと思われており，異物感染の報告があるにもかかわらず脳血管 内治療の分野に抢ける研究を見ない．今回，脳血管内治療の菌血症合併の現状について検討した。【方法】2006年 9 月から 2007年 9 月までの脑血管内治療153手技において，培養，血清検查を行い，菌血症の発生率，術野の清潔度，危険因子につ いて分析した.【結果】12例（7.8％) で菌血症が認められ全例抗生剤投与により軽快したが，MRSAによるものは難治性で あった，過半数の症例の術野から皮膚常在菌が検出された．菌血症の危険因子として術式（腫瘍塞栓術odds ratio [OR] 7.6, $\mathrm{P}=0.034)$ ，大きなシースサイズ(OR 3.9, $\mathrm{P}=0.047)$ の関連が有意であった。術野清潔度では，特定の術者（助手）（OR 0.5, $\mathrm{P}=0.049$ )の関連が有意であった。予防抗生剤投与例でも感染が有意に認められたため（OR 4.7, $\mathrm{P}=0.035 ）$ ，抗生剂は種類， 投与期間が重要であると考えられた。【結語】脳血管内治療に打いて予想以上に高率の菌血症が認められ，易感染者やシー スサイズの大きい複雑な手技には特に清潔操作に注意を要する. 